\title{
Globalization, Job Tasks and the Demand for Different Occupations
}

\section{Fredrik Heyman and Fredrik Sjöholm}

\section{(2) OpenEdition \\ 1 Journals}

\section{Electronic version}

URL: http://journals.openedition.org/travailemploi/8962

DOI: 10.4000/travailemploi.8962

ISSN: 1775-416X

\section{Publisher}

DARES - Ministère du Travail

\section{Printed version}

Date of publication: 1 January 2019

Number of pages: 67-92

ISSN: 0224-4365

\section{Electronic reference}

Fredrik Heyman and Fredrik Sjöholm, « Globalization, Job Tasks and the Demand for Different Occupations », Travail et Emploi [Online], 157 | 2019, Online since 01 January 2019, connection on 11 October 2019. URL : http://journals.openedition.org/travailemploi/8962 ; DOI : 10.4000/travailemploi. 8962 


\title{
Globalization, Job Tasks and the Demand for Different Occupations*
}

\author{
Fredrik Heyman $^{* *}$, Fredrik Sjöholm ${ }^{* * *}$
}

\begin{abstract}
Globalization has increased in recent decades, resulting in structural changes of production and labor demand. This paper examines how the increased global engagement of firms affects the structure of the workforce. We find that the aggregate distribution of occupations in Sweden has become more skilled between 1997 and 2013. Moreover, firms with a high degree of international orientation have a relatively skilled distribution of occupations and firms with low international orientation have a relatively unskilled distribution of occupations. High- and low-skilled occupations have increased in importance whereas middle-skilled occupations have declined with a resulting job polarization. We also discuss and analyze the role played by new technology and automatization.
\end{abstract}

$I^{n}$ nternational economic integration has increased substantially over the last decades and is presumably higher than ever before. One consequence of this is that a large share of workers are employed in foreign-owned firms, in firms that own foreign affiliates, and in exporting and offshoring firms. Globalization leads to an increased level of specialization in countries' production. Furthermore, globalization also results in increased competition, which, in turn, forces firms to engage in streamlining and improving their activities. Finally, globalization enables firms to benefit from economies of scale in production, which is particularly important for firms in relatively small countries. These effects of globalization have resulted in increased economic growth, higher incomes and improved living standards for large segments of the

\footnotetext{
* Acknowledgments: part of this paper is based on a report written in Swedish for the Centre for Business and Policy Studies (SNS). We thank members of the Centre, participants at the conference "Polarization(s) in Labour Markets" (Paris, June 2018), and the Editorial Board of Travail et Emploi for valuable comments and suggestions.

Fredrik Heyman and Fredrik Sjöholm acknowledge financial support from the Jan Wallanders och Tom Hedelius Stiftelse. Fredrik Heyman also acknowledges financial support from the Johan och Jakob Söderbergs Stiftelse, the Torsten Söderbergs Stiftelse and the Marianne och Marcus Wallenbergs Stiftelse and Fredrik Sjöholm from NORFACE.

** The Research Institute of Industrial Economics (IFN); Lund University, Sweden; fredrik.heyman@ifn.se.

*** Lund University; The Research Institute of Industrial Economics (IFN), Sweden; fredrik.sjoholm@nek.lu.se.
} 
population (FRANKEL, ROMER, 1999). However, what benefits individual countries, and the majority of people, does not necessarily benefit everyone. There are groups whose situation is rendered more difficult by the structural changes following increased levels of globalization. ${ }^{1}$

Furthermore, it appears that the nature of globalization has gradually changed. More specifically, structural change takes place within firms and between firms in the same industries, and not as before between different industries (BALDWIN, 2016). This change has an impact on the relative demand for different types of labor: some occupations face decreasing demand when their tasks are relocated to foreign countries, whereas others experience an increase in demand as a result of globalization.

New research shows that when China joined the World Trade Organization (WTO), it had a significant impact on the US labor market. Many American jobs disappeared because of increased imports from China, while approximately the same number of new American jobs were added when US exports increased (FEENSTRA, SASAHARA, 2017; FEENSTRA et al., 2017). But even if the net effect was marginal, the economic consequences were in many cases serious and long-lasting for the American workers who lost their jobs (AUTOR et al., 2014). While high-skilled workers managed relatively well and soon got new jobs in expanding industries, the low-skilled workers were severely affected. Decreasing incomes and increasing unemployment subsequently result in various negative effects, such as poor health, increased mortality and a decline in the number of new marriages and fertility (Autor et al., 2017; PIERCE, SCHOTT, 2016). ${ }^{2}$

Hence, it is clear that possible negative labor market effects may come with significant socioeconomic costs. This highlights the need for a better understanding of the mechanisms set in motion by increased globalization. It should be noted that the effect is more complex than what is captured by, for instance, the educational level of the workers: the effect of globalization is not uniformly benefitting skilled workers and hurting unskilled workers. Instead, the character of the job tasks carried out by different workers seems important in determining the effect of globalization. Some job tasks can be offshored to cheaper production sites in low-income countries whereas other tasks cannot. The latter include both high- and low-skilled tasks and many previous empirical studies show that it is primarily middle-skilled tasks that are declining. As a result, job polarization tends to increase (see e.g. Goos et al., 2014, for an overview).

This paper analyzes the effects of increased globalization with a particular focus on the relative demand for different occupations. Our analysis focuses on changes within firms and how these, in turn, alter the demand for different types of employees. The focus on firms allows us to present evidence on how these shape job polarization.

1. See, for example, Milanovic (2016) for an overview of the relationship between globalization and increased inequality. See also SAVAL (2017).

2. The increased globalization also has political implications. Citizens negatively affected by globalization have a tendency to be attracted to parties of a more protectionist or populist nature (RODRIK, 2018; AUTOR et al., 2016; DIPPEL et al., 2015; Colantone, StANIG, 2018a, 2018b). 
More specifically, it enables us to look at how organizational changes within firms influence the trend towards a more polarized labor market, and how the main explanations for job polarization are related to firm dynamics. We also briefly discuss and analyze the role played by new technology and automatization.

The tendency of increased job polarization has been shown in a large number of studies for different countries. Two early studies are Goos, MANNING (2007) and Goos et al. (2009). They look at the relationship between wages and employment at the level of individual occupations and the extent to which they are characterized as routine intensive. They find that occupations characterized as routine are in the middle of the wage distribution, while occupations not characterized as routine are in both the upper and lower end of the wage distribution. This indicates a potential improvement in employment opportunities for highly skilled occupations with relatively high wages as well as for low-skilled and low-wage occupations, as well as a less favorable development for middle-level occupations, mainly various white-collar occupations involving routine tasks. Hence, relative employment change is positively correlated with occupations that are non-routine and cognitive in nature and negatively correlated with occupations characterized as routine. This result is consistent with the task-biased technological change (TBTC) hypothesis and is one of the main explanations for the job polarization pattern observed in many countries. ${ }^{3}$ TBTC stresses that new technology affects occupations and job tasks differently. Some job tasks are complements and some are substitutes to new technology. Many occupations that are substitutes to new technology and that are routine-intensive are in the middle of the wage distribution. The decrease in demand for these occupations is in line with job polarization due to routine-biased (or task-biased) technological change. It is important to note that skill-biased technological change (SBTC), which for many years was the leading explanation for how relative labor demand and wage inequality were affected by changes in technology, is not able to explain job polarization because the task content of jobs is not part of the SBTC framework. This implies that SBTC cannot explain how globalization and new technology can affect relative labor demand differently in different parts of the wage distribution -in accordance with job polarization.

A number of studies have subsequently confirmed an improvement in employment opportunities for relatively high and relatively low wages and a weaker development for middle-level occupations, mainly various white-collar occupations (see, for example, Autor et al., 2006; ACEMOGlu, Autor, 2011; Asplund et al., 2011; Autor, Dorn, 2009, 2013; SPITZ-Oener, 2006; Michaels et al., 2014; Adermon, Gustavsson, 2015; Heyman, 2016).

We add to the literature above by putting a special focus on labor demand and job polarization in firms with different degrees of international integration. There are good reasons to believe that this factor may make a difference. For instance, the type of tasks required for operations on the domestic market might differ from the 
tasks required for export, offshoring, and other international activities. International finance and marketing, logistics, and other similar tasks required to run international operations are presumably of a high-skilled and non-routine character. As a result, there might be relatively more non-routine job tasks in globalized firms. Secondly, firms with for instance foreign affiliates are presumably in a relatively good position to divide the production chain and place different tasks in different countries. If this assumption is correct, we would expect relatively fewer routine- and low-skilled job tasks in multinational firms. At the opposite, local firms are not in the same position to use imported inputs, which means that the share of routine- and low-skilled employees can be expected to be comparably higher (see, for example, BECKER et al., 2013 and HAKKALA et al., 2014).

Our paper is structured as follows. We start by describing the mechanisms behind globalization and changes in labor demand. We also briefly discuss the link between new technology and relative labor demand. We then show how the distribution of occupations in firms has changed over time, depending on whether the firm is more or less globalized. This section also presents evidence on within-firm job polarization. We end with a discussion on how globalization and new technology affect job polarization.

\section{Globalization, Firms and the Labor Market}

Firms in specific industries differ considerably in a number of aspects. Some firms are large, use sophisticated technology and enjoy a high level of productivity, whereas others are small and have lower productivity. Furthermore, some firms have considerable international exposure with exports, imports of inputs and perhaps affiliates located abroad. Other firms are entirely focused on using domestic inputs and selling in the domestic market.

It is a stylized fact that multinational enterprises (MNEs) are more productive, pay higher wages, and perform more R\&D than domestic firms (e.g. BERNARD, JENSEN, 1997 and NAVARETTI, Venables, 2004). In his seminal work, DunNing (1981) provided an early explanation for this pattern, arguing that MNEs possess unique knowledge of production methods, management practices, or technologies. With the ownership of such firm-specific assets, MNEs are able to maintain the sales, profits, and productivity levels that are required to cover the additional costs associated with foreign expansion. Firm-specific assets have also been integrated into more formal models with heterogeneous firms in which firms select among different entry modes into a foreign market conditional on the quality of their firm-specific assets (see e.g. HelPMAN et al., 2004).

In HELPMAN et al. (2004) firms first draw their productivity from a given productivity distribution and then sort into three firm types according to their productivity draws. With fixed cost of entry being the lowest in the home market, firms in the lower part of the productivity distribution choose only to serve the home market (domestic 
firms). Firms in the middle part of the productivity distribution earn enough profit to cover a fixed exporting or marketing cost to also reach consumers in foreign markets by exporting (exporting firms). Firms in the top-end of the source country productivity distribution can additionally cover the fixed cost of opening an affiliate in the foreign market, and avoid variable trade costs associated with exporting. Thus, MNEs are the most productive firm type, local firms the least productive, and exporters have an intermediate productivity level. In our empirical analysis, we will focus on these three firm types.

Developments in information and communication technology (ICT) have resulted in firms being able to more easily break up production chains and move different tasks to different geographical locations. The main reason is that it has become easier to communicate over long distances and manage logistical needs across national boundaries. As a result, firms have become more complex. MNEs have been at the forefront of a process where different parts of the production are located in different facilities and frequently also to different countries. To an increasing extent, different components are produced in different geographical locations and then shipped to other factories where they are assembled into finished products and exported worldwide. This division applies not only to the production of goods, such as components and other inputs, but also to the production of services, such as design, logistics, and marketing. Firms may increase their profitability by separating the production and locating each task where it is the cheapest and the most effective.

In the recent academic literature on global value chains, the concept of trade in tasks is frequently used as a complement to defining production units in terms of produced goods or inputs (Grossman, Rossi-HANSBERG, 2008, 2012). Characteristics other than knowledge intensity and formal training then lead to the decision whether or not a task may be carried out at a longer distance from the head office. For instance, the degree of routine tasks and the need for close communications are important determinants of what may be relocated to other countries and what needs to be located in the home country. There are tasks that can easily be codified and do not require close monitoring or interaction with the head office or other parts of the production. Many, but not all, such tasks are routine in nature and can be carried out by low-skilled labor. Computer programming is an example of the opposite; this work requires a high level of education but may easily be performed by an engineer working in, for example, India. Cleaning and repair services, on the other hand, are examples of tasks often performed by low-skilled labor, but which are difficult to relocate far away from the rest of the operations.

All in all, this means that the relationship between the knowledge intensity of job tasks and how suitable they are for relocation is complex, which in turn means that job tasks and occupations involving both a high and a low level of knowledge are affected by increased globalization (BLINDER, 2006; BLINDER, KRUEGER, 2013; HaKKaLA et al., 2014). 
Globalization represents an important explanation for changes in demand for different types of labor, even though globalization clearly is not the only explanation. Technological development is frequently presented as another important factor behind changes in the labor market. Technology and globalization are, however, closely linked, thereby making it difficult to distinguish their effects. More specifically, new technology increases the degree of globalization, but there is also an effect of increased globalization on the development of new technology. New technological developments can therefore potentially amplify or change the way globalization impacts workers and firms. Similarly, changes in globalization can influence how new technology affects workers and firms. We will take this possible effect into account in the empirical analysis by including measures on technology.

Extensive research has shown, in accordance with SBTC, that technology shifts are associated with a higher demand for skilled workers since mastering new and more complex technology often requires a higher level of education. In recent years, however, many studies have shifted the view that education is crucial to the way technology affects different groups, particularly since SBTC is unable to explain a number of important phenomena in the labor market observed in recent years. As mentioned above, one important reason for this is that the analysis based on SBTC does not take into account the task content of jobs. Instead, and as discussed above, TBCT emphasizes the nature of the tasks performed by workers (see LEAMER, STORPER, 2001; Autor et al., 2003 and Levy, MuRMANE, 2004 for three early contributions).

The job task literature and TBCT stress that the specific task contents in occupations determine how new technologies affect the relative labor demand. ${ }^{4}$ Different types of tasks can either complement new technology or be substituted by it and this, rather than formal education, is precisely what will determine how different jobs are affected. Well-defined tasks that may be described in the form of clear rules, jobs of a so-called routine nature, could be substituted by new technologies. Tasks characterized as complex and requiring elements such as problem-solving (i.e. nonroutine jobs) instead serve as complements to new technology. The increased use of ICT may thus be expected to reduce the demand for workers with routine jobs and increase the demand for non-routine jobs, which may be seen as complementing new technology. This development is in line with the extensive international evidence on job polarization. However, it should be emphasized that the relationship between new technology and demand for labor is complex and routine tasks can also be difficult to automate (AUTOR, 2014). ${ }^{5}$

4. See also ACEMOGLU, AUTOR (2011) for a more developed model incorporating SBTC and the importance of specific tasks (demand for routine and non-routine jobs). AUTOR (2013) is a summarizing paper on how job task contents and technology affect labor markets.

5. Autor (2014) discusses the relationship between digitalization and the demand for different types of tasks on the basis of the so-called Polanyi's Paradox. Polanyi's Paradox says that many simple tasks may be surprisingly difficult to automate. AUTOR (2014) further argues that complementary effects between new technology and labor may be significant. 
Globalization is also closely related to the routinization of jobs. A large empirical literature has presented evidence on how globalization affects the relative demand for routine jobs (see e.g. BeCKer et al., 2013; BAUMGARTEN et al., 2013; and HAKKALA et al., 2014). These papers show that increased globalization tends to increase the demand for non-routine jobs and jobs characterized by personal interaction. For instance, results in HAKKALA et al. (2014) indicate that MNEs employ a higher share of non-routine jobs and that acquisitions of local firms by MNEs tend to increase the relative demand for non-routine and interactive job tasks. This suggests that foreign direct investments (FDI) increase the demand for non-routine and interactive tasks, hence a link between globalization and de-routinization of jobs. Another link between globalization and routinization of jobs, analyzed in e.g. BAUMGARTEN et al. (2013), is how offshoring affects the relative demand for jobs in terms of their routine content. Since routine tasks and tasks that do not require personal interaction can be more easily located at a distance from the home country, this implies that increased offshoring leads to a de-routinization of jobs in the home country.

We now continue by presenting empirical evidence on how globalization affects labor markets with a particular focus on relative demand for different occupations and job polarization. We also discuss our results in relation to the international evidence on relative labor demand and job polarization.

\section{Globalization and the Organization of Firms: Empirical Evidence}

\section{Swedish Matched Employer-Employee Data}

We will use detailed, register-based, matched employer-employee data from Statistics Sweden (SCB) to examine how globalization shapes the relative demand for different occupations. The database includes data on firms and individuals, which are linked with unique identification numbers and cover the period from 1996 to 2013. The firm data contain detailed information on all Swedish firms, including variables such as value added, capital stock (book value), number of employees, wages, ownership status, sales, and industry. The data on individuals originate from Sweden's official wage statistics and contain detailed information on a representative sample of the labor force, including full-time equivalent wages, education, occupation, and gender. Occupations are based on the Swedish Standard Classification of Occupations (SSYK96) which in turn is based on the International Standard Classification of Occupations (ISCO-88).

Firm-level data on exports and imports by product and country of origin come from the Swedish Foreign Trade Statistics, collected by Statistics Sweden. ${ }^{6}$ Based on

6. These data cover the period 1997-2013. 
compulsory registration at Swedish Customs, the data cover all the trade transactions from outside the EU. Trade data for EU countries are available for all firms with a yearly import or export of around 1.5 million $\mathrm{SEK}^{7}$ and above. Material imports are defined at the 5-digit level according to NACE Rev 1.1 and grouped into Main Industrial Groupings (MIGs) based on intended use. Based on the MIGs definition of intermediate inputs we identify offshoring using import data at the firm and product level.

Information on foreign MNEs operating in Sweden comes from the Swedish Agency for Economic and Regional Growth (Tillväxtanalys). The Agency uses definitions that are in accordance with definitions concerning similar data from the OECD and Eurostat. A firm is classified as a foreign-owned MNE if more than 50\% of the equity are foreign-owned. Finally, Swedish MNEs are defined as firms reporting positive exports to other firms within the corporation.

All data sets are matched by unique identification codes. We restrict our analysis to firms with at least ten non-farm private sector employees who are observed throughout the period.

\section{Relative Demand for Different Occupations Over Time}

As discussed above, there are reasons to expect that increased internationalization has an effect on how firms organize production. Below, we compare the relative occupational structures in firms with different degrees of international involvement in order to examine the effect of globalization on the occupational composition.

We first rank occupations by average wage level over the period 1997-2013 at the national level. ${ }^{8}$ The highest average wages (highest ranks) are found for chief executive officers (CEOs), lawyers, and healthcare specialists. The lowest average wages are observed for cleaners, and kitchen and restaurant workers. We then measure the share of the workforce in the different occupations at the firm level. For each firm, we compute an index that summarizes the ranks of the occupations weighted by their share in the firm's workforce. The firm index varies between 0.01 and 1 , and a high index means a high level of employment in high-wage occupations. ${ }^{9}$

Figure 1 shows the average national index for the period 1997-2013. The index was stable up until 2007. After 2007, the index has continuously increased: it was about 0.54 in 2007 , while it had increased to about 0.59 by 2013 . This means that the occupational composition has become more skilled: an increasing share of the workforce is working in relatively skilled occupations and a decreasing share in relatively less skilled occupations.

7. Swedish Krona (around 140,000 Euros).

8. See DAVIDSON et al. (2017) for results and details regarding different alternative occupational rankings. These include ranking (i) on the basis of wages in non-MNEs (in order to take higher wages in MNEs into account), (ii) on the basis of education, and (iii) on the basis of a regression approach where we take various individual characteristics into account. The results are robust and do not change depending on our choice of ranking.

9. See DAVIDSON et al. (2017) for details regarding this index. 
FIGURE 1 - Evolution of the Occupational Composition in Sweden 1997-2013 (Index)

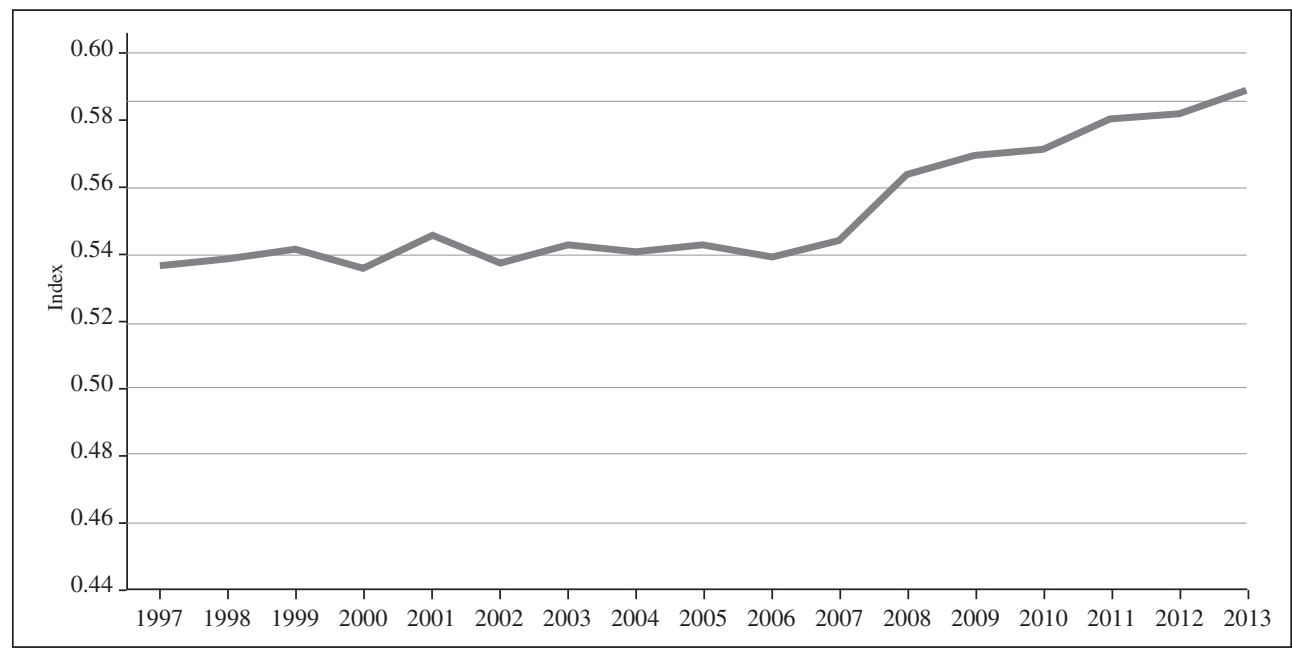

Note: The index is estimated at the firm level. A high value represents a relatively skilled occupational composition. The figure shows annual averages at the national level. See DAVIDSON et al. (2017) for details.

A similar picture is presented in Figure 2, showing the evolution in employment shares for 21 specific occupational categories. In order to be able to make a comparison with the work by Goos et al. $(2009,2014)$ on job polarization, we have applied the same grouping of occupations. Figure 2 suggests that the pattern in Figure 1 is more complex than an increase in the share of the most skilled employees and a decrease in the lowest skilled employees. The general trend is an increase in the skill level (Figure 1) but there are dramatic changes in the skill distribution (Figure 2). More specifically, the largest increase is seen for both occupations at the top and at the bottom of the wage distribution. For low-wage occupations, we see an increase in employment shares for occupations in the service, care and security sectors and for different types of services requiring a low level of education only. High-wage occupations increasing in employment shares include various specialist and managerial occupations. We also note a reduction in relative shares for a number of occupations, several of which are located in the middle of the wage distribution. These include occupations in machine and assembly work in addition to metal and repair work. All in all, the changes in Figure 2 support the presence of job polarization, i.e. the simultaneous growth of high-skilled, high-wage jobs and low-skilled, low-wage jobs at the expense of middleskilled jobs. 
FIGURE 2 - Changes in Employment Shares for Different Occupational Categories 1996-2013

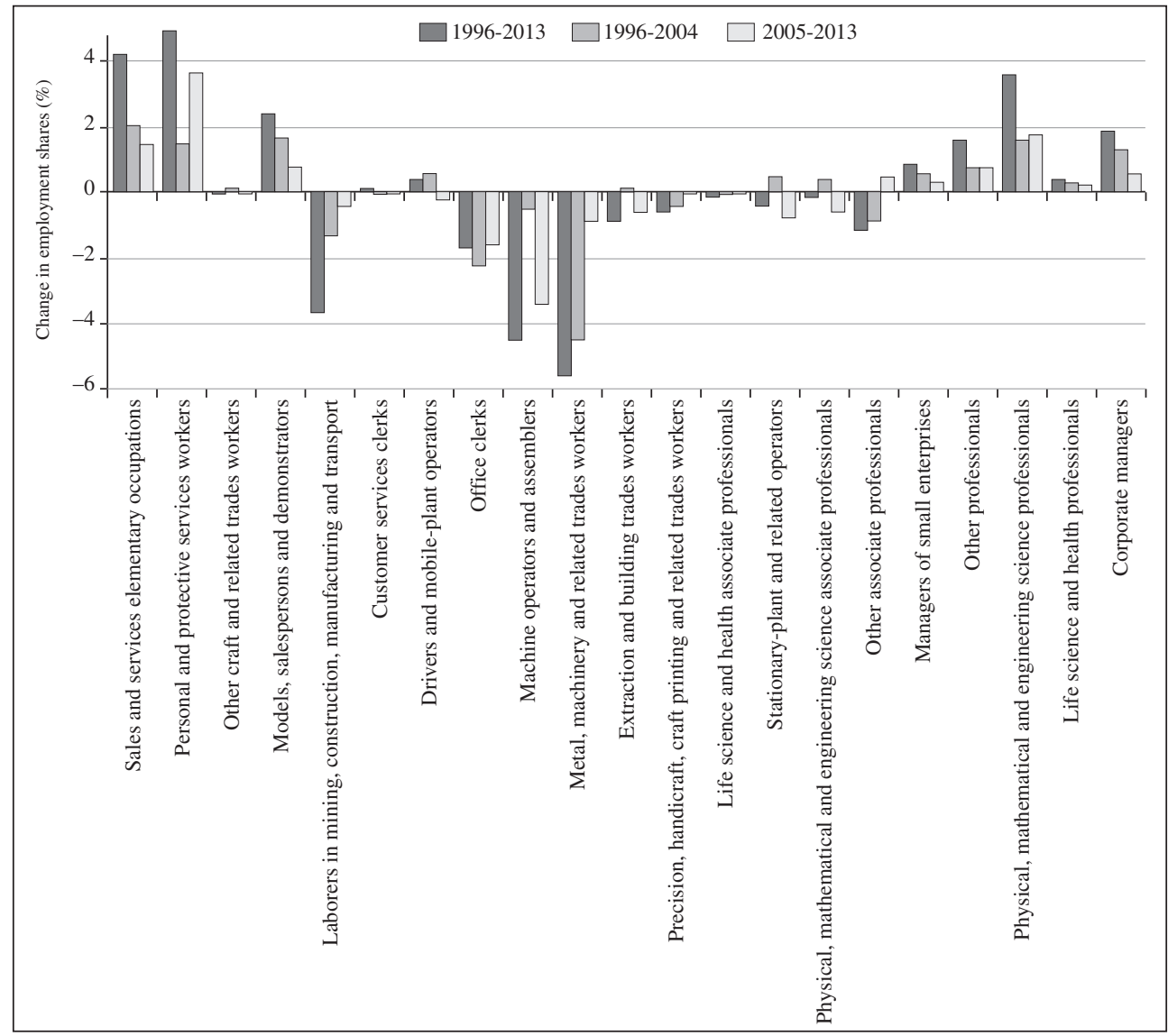

Note: The occupational distribution is identical to the one used in Goos et al. (2014). The least skilled occupation on the basis of wages is found on the left and the most skilled on the right.

Source: Heyman (2016).

\section{Job Polarization within Firms}

The job polarization literature typically focuses on employment changes in different occupations, with no consideration given to how firms shape the labor demand process, but there are a few exceptions. One is Heyman (2016) who uses detailed matched firm-worker data for Sweden spanning the period 1996-2013 to investigate the role played by firms in the recent trend toward a more polarized labor market. The study presents results that show novel evidence on within-firm job polarization. Accordingly, KERR et al. (2016) find evidence of job polarization within Finnish firms and that this polarization is also influenced by the entry and exit of firms. They also find that increased trade and offshoring play a role in terms of job polarization. Finally, HARRIGAN et al. (2016), who study French firms, find that job polarization occurs both within and between firms. 
Changes in employment can be decomposed into a within-industry component and a between-industry one. Goos et al. (2014) find that both components are qualitatively important in terms of explaining the overall pattern in their study on 16 European countries. Hence, job polarization is driven by both employment dynamics within industries as well as between industries. We present similar results based on our

\section{FIGURE 3 - Changes in Employment Shares 1996-2013}

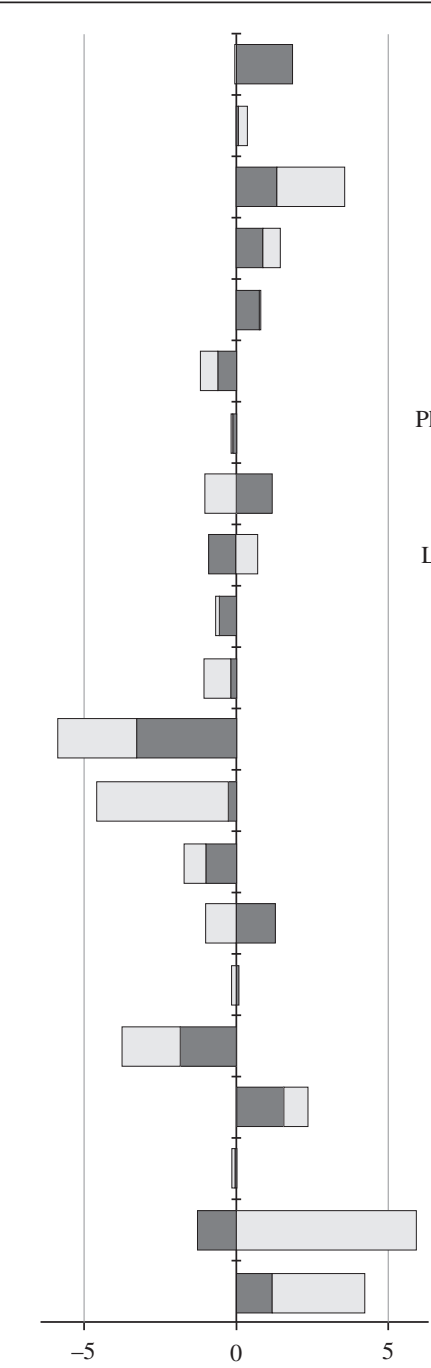

Fig. 3a - Within and between Industries

\section{Corporate managers}

Life science and health professionals

Physical, mathematical

and engineering science professionals

Other professionals

Managers of small enterprises

Other associate professionals

Physical, mathematical and engineering science associate professionals

Stationary-plant and related operators

Life science and health associate professionals

Precision, handicraft, craft printing and related trades workers

Extraction and building trades workers

Metal, machinery and related trades workers

Machine operators and assemblers

Office clerks

Drivers and mobile-plant operators

Customer services clerks

Laborers in mining, construction, manufacturing and transport

Models, salespersons and demonstrators

Other craft and related trades workers

Personal and protective services workers

Sales and services elementary occupations

Within Between

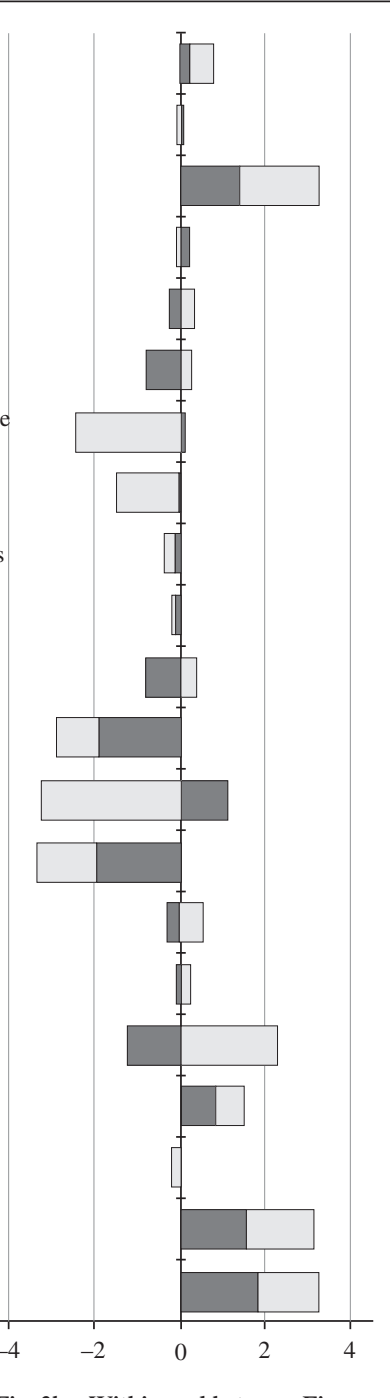

Fig. $3 b-$ Within and between Firms

Note: The figures show decompositions of changes in employment shares for the period 1996-2013. Occupations are based on ISCO-88 and are ordered by their mean wage in the first year (1996). Each bar represents percentage point changes in employment shares between 1996 and 2013.

Source: HEYMAN (2016). 
matched-employer-employee data to see if the same pattern is present in Sweden. ${ }^{10}$ In addition to studying industry components, we extend the analysis in Goos et al. (2014) by looking at employment dynamics at the firm level and the importance of within-firm and between-firm components of overall job polarization. Figure 3 a presents results using industry decomposition and Figure $3 \mathrm{~b}$ shows corresponding results at the firm level. Both industry components are typically positive for high-wage and low-wage occupations and are mostly negative for the group of middle-wage occupations.

Occupations are also divided into three wage groups as in Goos et al. (2009, 2014). We observe a 6.7 percentage point increase in the employment share for the high-wage group, a decrease in the middle-wage group equal to 17.8 percentage points and an increase in the low-wage group equal to 11.1 percentage points. Both industry components are positive for the high-wage and low-wage groups and are negative for the middle-wage group. These results are in accordance with results in Goos et al. (2014) and indicate that overall job polarization originates from both within- and between-industry reallocation.

Similar patterns can also be traced at the firm level (Figure 3b). One difference is related to changes in employment shares for low-wage jobs. For this wage group, the intra and inter components are generally stronger at the firm level than at the industry level, suggesting that the increasing demand for low-wage jobs is much more due to reallocation at the firm level, both within and between firms, than reallocations within and between sectors. These results are in accordance with recent research stressing the importance of firm heterogeneity (see, for example, MeLiTz, 2013).

After showing descriptive evidence on overall job polarization in Sweden, we now present regression results at the firm-level. We estimate within-firm regression models where the shares of workers in the three wage groups are regressed on year dummies. All regressions also include time-varying firm characteristics and firm fixed-effects. Details can be found in HEYMAN (2016).

Figure 4 presents the results. The figure plots the estimated coefficients for the year dummies for the three different wage groups. ${ }^{11}$ Hence, Figure 4 shows annual changes in employment shares and not the overall change in employment between 1996 and 2013. There is an increasing trend in the share of employees in the high-wage group, while at the same time, the share of middle-wage group workers decreases within firms over time. These two developments are consistent with within-firm job polarization. The annual changes in low-wage employment are less clear. However, the estimated coefficients are systematically positive during the period for the low-wage group and are added up to positive changes observed in accordance with the results in Figures 2 and 3. Overall, the evidence in Figure 4 points to a divergence in employment dynamics across occupations at different parts of the wage distribution.

10. The results and discussion in this section are based on results in HEYMAN (2016).

11. The exact estimates are available upon request. 
FIGURE 4 - Within-Firm Job Polarization in Sweden, 1996-2013

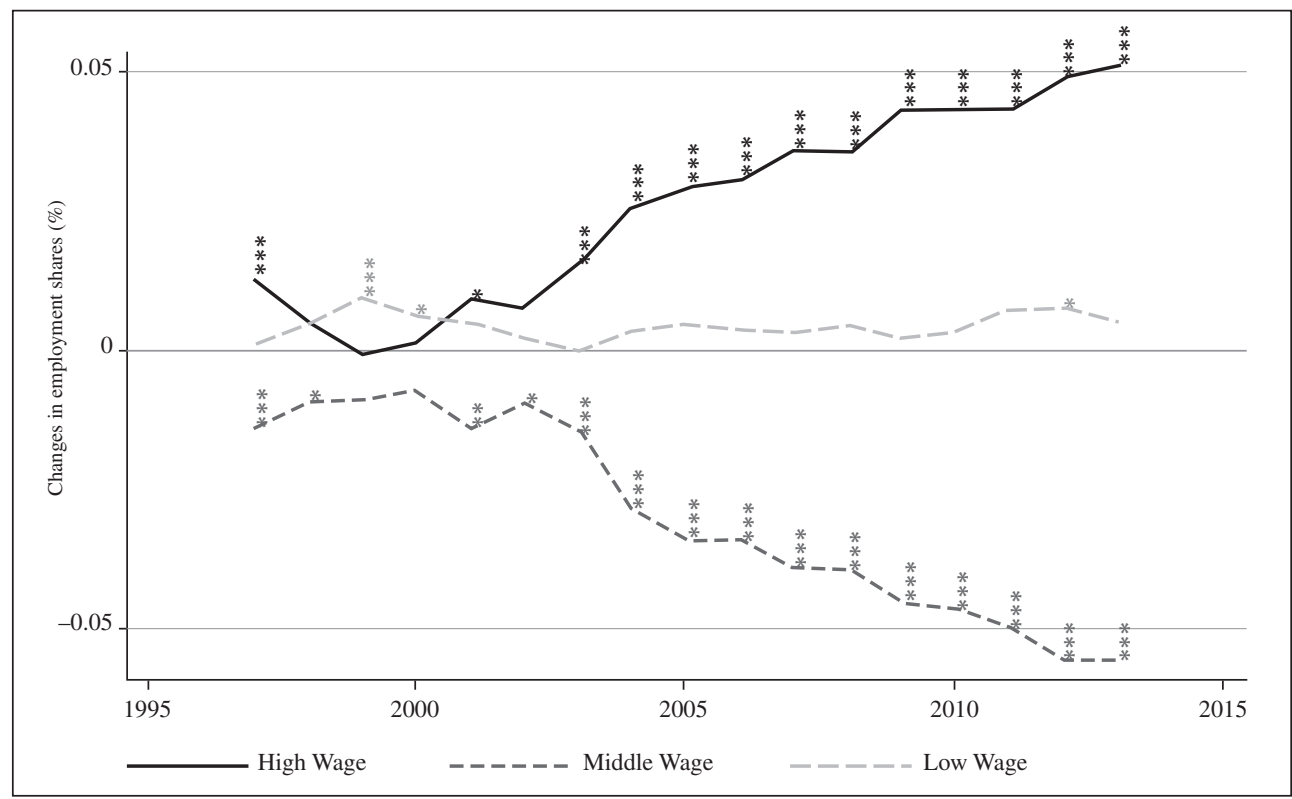

Note: Job polarization in Sweden 1996-2013. Estimated coefficients on occupation group-year dummies. The figure plots estimated year coefficients obtained from equation (1) in Heyman et al. (2016). Stars denote the level at which the estimated coefficients are significantly different from zero. To allow for within-firm correlation over time, standard errors are adjusted for clustering at the firm level. $* * *, * *, *$ show significance at the $1 \%, 5 \%$, and $10 \%$ level, respectively.

Source: HeYMAN (2016).

\section{How are the Different Occupational Categories Affected by Globalization?}

We continue our analysis by looking in more detail at the extent to which changes in globalization are related to changes in the relative demand for different occupations (Table 1). The classification into low- and high-skilled occupations is based on the average wage over the period 1997-2013, as shown in column 1. Managerial employees have the highest average wage and laborers have the lowest. The difference in wages between these two groups is approximately 130 percent. Column 2 shows the shares of total employment for the occupational categories, and column 3 shows the corresponding wage cost shares.

Columns 4-7 show the corresponding shares in the manufacturing industry and the service sector, respectively. The largest differences are found in the less skilled occupations: machine operators represent a large group within the manufacturing sector but a very small group in the service sector, whereas service and sales workers represent a large group in the service sector but are non-existent in the manufacturing sector.

Next, we divide our firms into three types and estimate regressions at the firm level to compare firms with different levels of international engagement. As previously mentioned, our firm types are MNEs, which are the most globally integrated firms; nonMNEs that do not export (i.e. local firms), which are the least globally integrated; and 


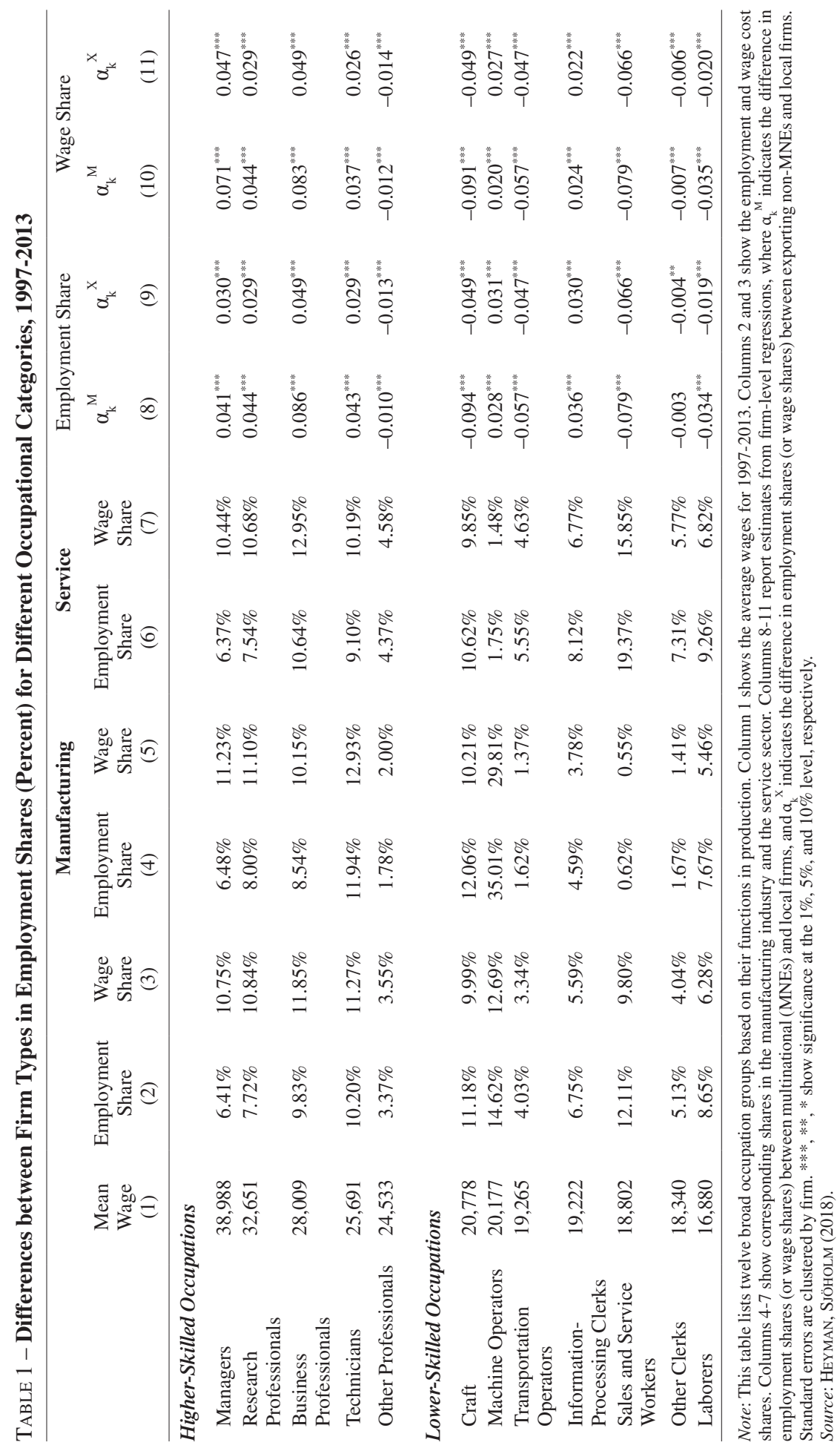


non-MNE exporters, which represent an intermediate degree of global integration. The dependent variable is the occupational share, and the regressions control for time and industry variation as well as for a variety of firm characteristics, such as size, capital intensity, firm age and labor productivity (see DAVIDSON et al., 2017, for details).

The results for MNEs and exporters are shown in columns 8-11 and are based on both employment shares and wage shares. $\alpha_{k}^{M}$ is an estimate of the share of a given occupational category working in MNEs in comparison with the share employed in local firms after we have taken the above mentioned firm-specific factors into account. A positive coefficient means that MNEs have a relatively large share of the occupational category in question compared to similar local firms. A negative coefficient means that they have a relatively small share in relation to local firms. In the same way, $\alpha_{k}^{X}$ captures the share of an occupational category in exporting firms compared to the share in local firms.

For instance, looking at managers, and on the basis of employment shares, we observe that the estimated coefficient for $\alpha_{k}^{M}$ is equal to 0.04 . This means that in comparison with local firms, the share of managers is 4 percentage points higher for MNEs. The corresponding estimate for exporters, $\alpha_{k}^{X}$, is approximately 0.03 , indicating that the share of managerial employees is on average 3 percentage points higher for exporters compared to local firms.

As we can see in Table 1, MNEs and exporters have a larger share of employees within highly skilled occupations compared to local firms. The difference between local and globalized firms is particularly significant with regard to legal and financial specialists; MNEs employment share is close to 4 percentage points larger than local firms. Furthermore, we see that the coefficient for $\alpha_{k}^{M}$ in all high-skilled occupational categories. This means that the shares are larger in MNEs than in exporting firms. In other words, we observe the largest shares of high-skilled occupations in MNEs followed by exporting firms and then by local firms.

The results for less-skilled occupations are basically a mirror image of the above results. MNEs and exporting firms generally have a relatively low share of low-skilled jobs. The exceptions are machine operators and information assistants, of which local firms have relatively low shares. The difference between local firms and globalized firms is particularly significant for construction workers and for service and sales workers. Furthermore, the coefficient for MNEs tends to be smaller than the coefficient for exporting firms. This indicates that for less skilled occupational categories, MNEs tend to have the smallest employment shares, local firms the largest shares and exporting firms somewhere in-between.

\section{A More General Picture of the Occupational Distribution in Different Firm Types}

We also analyze how the overall occupational distribution differs between different firm types (Figure 5). Along the x-axis, we have ranked our 100 occupations from the least skilled to the most skilled. Just like before, the ranking is based on the 
FIGURE 5 - Composition of Occupations Based on Skill Levels in Different Firm Types, 1997-2013

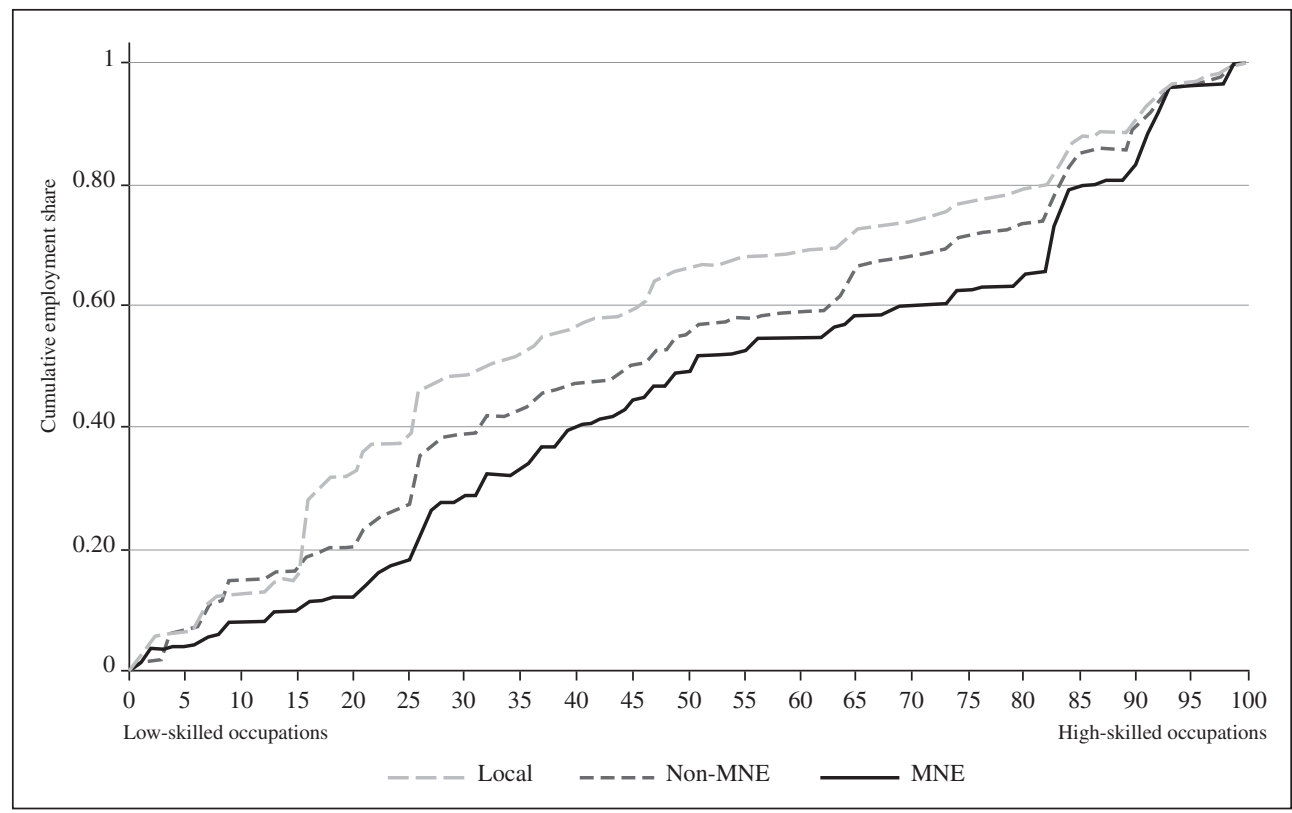

Note: "Local" are non-exporters that are not MNEs, "Non-MNE" are exporters that are not MNEs and "MNE" are multinational enterprises. See DAVIDSON et al. (2017) for details.

average wage for the occupations throughout the period. The y-axis corresponds to the cumulative employment share of the labor force accounted for by the skill category that is indicated on the $\mathrm{x}$-axis. If all occupations represented the exact same share of the workforce, we would have a 45-degree straight line. The curves for the three firm types differ, indicating differences in the shares of different occupations for different firms. The curve for local firms appears above the curve for exporters and a little more above the curve for MNEs. This is a result of the relatively large share of low-skilled occupations in local firms. For instance, we observe that the 50 percent lowest-skilled occupations account for almost 70 percent of employees in the least globalized firms (local) and about 50 percent in the most globalized firms (MNEs). Exporters have a share located somewhere in-between local and multinational firms. The results in Figure 5 illustrate that firms level of globalization is positively correlated with the share of highly skilled occupations. This in turn implies a positive relationship between the presence of local firms and the relative demand for low-skilled jobs. Overall, the results in Figure 5 are in accordance with a job polarization pattern where globalized firms have employed an increasing number of high-skilled jobs at the same time as local firms have increased their share of low-skilled occupations.

Yet another way of analyzing the difference in occupational composition is to use our previously defined index in regressions with different firm types and different control variables as explanatory variables. In Table 2, we only show the estimated 
TABLE 2 - Differences in Occupational Structures between Different Firm Types. Firm-Level Regressions, 1997-2013

\begin{tabular}{lccc}
\hline & $(\mathbf{1})$ & $(\mathbf{2})$ & $(\mathbf{3})$ \\
\hline MNE & $0.137^{* * * *}$ & $0.116^{* * * *}$ & \\
& $(0.004)$ & $(0.004)$ & \\
Non-MNE Exporter & $0.092^{* * * *}$ & $0.074^{* * * *}$ & \\
& $(0.004)$ & $(0.003)$ & \\
Offshoring & & $0.050^{* * * *}$ & $0.084^{* * * *}$ \\
& & $(0.003)$ & $(0.004)$ \\
Foreign MNE & & $0.083^{* * * *}$ \\
& & & $(0.005)$ \\
Swedish MNE & & & \\
\end{tabular}

Note: This table shows estimated coefficients from regressions with an index of the skill level in the firms' workforce as dependent variable. The regressions are at the firm level and cover the period 1997-2013. The estimated coefficients show the skill level in the occupational composition compared to the composition in local firms. A positive estimated coefficient indicates that a firm type has a more skilled occupational composition than local firms. All regressions control for firm size, capital intensity, value added per employee and firm age. They also control for industry-specific and year-specific factors. The regressions are based on 69,109 observations. To allow for within-firm correlation over time, standard errors are adjusted for clustering at the firm level. ${ }^{* * *},{ }^{* *},{ }^{*}$ show significance at the $1 \%, 5 \%$, and $10 \%$ level, respectively

Source: Heyman, SJöHolm (2018). See also Davidson et al. (2017) for details.

coefficients for our firm types, which show the difference in the skill index for different globalized firms as compared to local firms. For instance, a positive coefficient means that the firm in question has a distribution of occupations more geared towards highly skilled occupations than local firms.

In column 1, we compare MNEs and exporters with local firms. The results show that MNEs have the most skilled occupational composition in comparison with the other firm types: MNEs have more employees in high-wage occupations and fewer employees in low-wage occupations. Non-MNE exporters have an occupational composition between MNEs and local firms.

We previously discussed offshoring as an additional dimension of international integration. In column 2 we examine if offshoring has an impact on the occupational mix. Offshoring is measured by imported inputs as a share of total sales. As shown in column 2, the inclusion of offshoring has little impact on our main results. Although the offshoring coefficient is statistically significant, the main result is driven by the fact that MNEs or exporters employ much more skilled jobs than local firms.

In the last column, we look at occupational differences on the basis of multinational ownership and show differences between different types of MNEs. The results indicate that there is no difference between Swedish and foreign-owned MNEs; both firm types have a relatively skilled occupational composition. 


\section{Do Globalization and New Technology Contribute to Within-Firm Job Polarization?}

Figures 2-4 showed job polarization to have increased in Sweden. In Table 3, we examine the main determinants to the increased job polarization. The focus is on the results on within-firm polarization presented above. The results and discussion in this section is based on HeYman (2016).

As discussed above, it is of course difficult to distinguish between the technological effect and that of globalization. Many of the same arguments on how new technology and routineness of jobs influence different occupations can also be applied to the impact of international trade and offshoring. Sorting out the relative importance

TABLE 3 - Routineness, Automation, Offshoring and Job Polarization at the Firm Level. Firm-Level Regressions, 1996-2013

\begin{tabular}{|c|c|c|c|c|c|c|}
\hline & $\begin{array}{c}\text { High Wage } \\
\text { Group } \\
\text { (1) }\end{array}$ & $\begin{array}{c}\text { High Wage } \\
\text { Group } \\
(2)\end{array}$ & $\begin{array}{l}\text { Middle Wage } \\
\text { Group } \\
\text { (3) }\end{array}$ & $\begin{array}{l}\text { Middle Wage } \\
\text { Group } \\
\text { (4) }\end{array}$ & $\begin{array}{c}\text { Low Wage } \\
\text { Group } \\
(5)\end{array}$ & $\begin{array}{c}\text { Low Wage } \\
\text { Group } \\
(6)\end{array}$ \\
\hline & Low & High & Low & High & Low & High \\
\hline \multicolumn{7}{|c|}{ Panel a: Routineness } \\
\hline D_1999-2003 & $\begin{array}{c}-0.012^{* * *} \\
(0.005)\end{array}$ & $\begin{array}{c}0.006 \\
(0.004)\end{array}$ & $\begin{array}{l}0.014^{* * * *} \\
(0.005)\end{array}$ & $\begin{array}{c}-0.011^{* * * *} \\
(0.004)\end{array}$ & $\begin{array}{l}-0.002 \\
(0.004)\end{array}$ & $\begin{array}{c}0.006^{*} \\
(0.003)\end{array}$ \\
\hline D_2004-2008 & $\begin{array}{c}-0.010^{*} \\
(0.006)\end{array}$ & $\begin{array}{l}0.042^{* * * *} \\
(0.005)\end{array}$ & $\begin{array}{l}0.023^{* * *} \\
(0.006)\end{array}$ & $\begin{array}{c}-0.056^{* * * *} \\
(0.006)\end{array}$ & $\begin{array}{c}-0.013^{* *} \\
(0.005)\end{array}$ & $\begin{array}{l}0.014^{* * *} \\
(0.004)\end{array}$ \\
\hline D_2009-2013 & $\begin{array}{l}-0.007 \\
(0.007)\end{array}$ & $\begin{array}{l}0.064^{* * *} \\
(0.006)\end{array}$ & $\begin{array}{l}0.020^{* * * *} \\
(0.007)\end{array}$ & $\begin{array}{c}-0.078^{* * * *} \\
(0.006)\end{array}$ & $\begin{array}{c}-0.013^{* *} \\
(0.006)\end{array}$ & $\begin{array}{c}0.014^{* * *} \\
(0.004)\end{array}$ \\
\hline \multicolumn{7}{|l|}{ Panel b: Offshoring } \\
\hline D_1999-2003 & $\begin{array}{l}0.008^{* *} \\
(0.004)\end{array}$ & $\begin{array}{c}-0.008^{*} \\
(0.004)\end{array}$ & $\begin{array}{c}-0.008^{*} \\
(0.005)\end{array}$ & $\begin{array}{c}0.004 \\
(0.005)\end{array}$ & $\begin{array}{c}0.000 \\
(0.004)\end{array}$ & $\begin{array}{l}0.005^{* *} \\
(0.002)\end{array}$ \\
\hline D_2004-2008 & $\begin{array}{l}0.020^{* * * *} \\
(0.005)\end{array}$ & $\begin{array}{l}0.023^{* * * *} \\
(0.005)\end{array}$ & $\begin{array}{c}-0.013^{* *} \\
(0.006)\end{array}$ & $\begin{array}{c}-0.034^{* * * *} \\
(0.006)\end{array}$ & $\begin{array}{l}-0.007 \\
(0.006)\end{array}$ & $\begin{array}{l}0.011^{* * * *} \\
(0.003)\end{array}$ \\
\hline D_2009-2013 & $\begin{array}{l}0.033^{* * *} \\
(0.006)\end{array}$ & $\begin{array}{l}0.036^{* * * *} \\
(0.006)\end{array}$ & $\begin{array}{c}-0.024^{* * *} \\
(0.007)\end{array}$ & $\begin{array}{c}-0.049^{* * * *} \\
(0.006)\end{array}$ & $\begin{array}{l}-0.009 \\
(0.007)\end{array}$ & $\begin{array}{l}0.012^{* * *} \\
(0.003)\end{array}$ \\
\hline \multicolumn{7}{|l|}{ Panel c: Automation } \\
\hline D_1999-2003 & $\begin{array}{c}0.003 \\
(0.005)\end{array}$ & $\begin{array}{l}-0.004 \\
(0.004)\end{array}$ & $\begin{array}{l}-0.006 \\
(0.005)\end{array}$ & $\begin{array}{c}0.002 \\
(0.005)\end{array}$ & $\begin{array}{c}0.004 \\
(0.003)\end{array}$ & $\begin{array}{c}0.002 \\
(0.003)\end{array}$ \\
\hline D_2004-2008 & $\begin{array}{l}0.021^{* * *} \\
(0.006)\end{array}$ & $\begin{array}{c}0.023^{* * * *} \\
(0.005)\end{array}$ & $\begin{array}{c}-0.025^{* * * *} \\
(0.006)\end{array}$ & $\begin{array}{c}-0.026^{* * * *} \\
(0.006)\end{array}$ & $\begin{array}{c}0.004 \\
(0.003)\end{array}$ & $\begin{array}{c}0.003 \\
(0.005)\end{array}$ \\
\hline D_2009-2013 & $\begin{array}{l}0.031^{* * * *} \\
(0.007)\end{array}$ & $\begin{array}{l}0.039^{* * * *} \\
(0.006)\end{array}$ & $\begin{array}{c}-0.035^{* * * *} \\
(0.006)\end{array}$ & $\begin{array}{c}-0.043^{\text {**** }} \\
(0.007)\end{array}$ & $\begin{array}{c}0.004 \\
(0.004) \\
\end{array}$ & $\begin{array}{c}0.003 \\
(0.006) \\
\end{array}$ \\
\hline Firm Controls & Yes & Yes & Yes & Yes & Yes & Yes \\
\hline Firm Fixed Effects & Yes & Yes & Yes & Yes & Yes & Yes \\
\hline
\end{tabular}

Note: The dependent variable is the share of high-, medium- and low-wage employees at the firm level. Low and high in columns 1-6 refer to initial values of routineness, automation and offshoring. For each wage group, firms are divided into two groups, high and low, based on initial values of routineness, automation and offshoring. Firm controls include the log of value added per employee and the log of the capital-labor ratio. Firm and year fixed effects are included in all estimations. To allow for within-firm correlation over time, standard errors are adjusted for clustering at the firm level. ${ }^{* * *},{ }^{* *},{ }^{*}$ show significance at the $1 \%, 5 \%$, and $10 \%$ level, respectively. Source: HEYMAN (2016). 
of these factors is difficult and outside the scope of this paper. In this paper, we instead show regression-based evidence on how routineness, offshoring and automation of jobs correlate with the observed pattern of within-firm job polarization. We refer to Heyman (2016) for more details.

Panel a in Table 3 shows results on routineness, panel $b$ on offshoring and panel $\mathrm{c}$ on automation. To investigate how the degree of routineness of jobs is related to within-firm job polarization we divide firms into two groups according to the intensity of routineness for the firm's workforce in their initial year. Routineness is defined by the routine task-intensity (RTI) index used in e.g. AutOR (2013), AUTOR, DORN (2013), and Goos et al. (2014). RTI is available at the 2-digit level for the Swedish job classification, SSYK96. A higher value indicates that the occupation is characterized by more routine tasks. We then estimate separate regressions on each wage group and on each group according to the intensity of routineness. The hypothesis is that firms with a high initial share of employees with routine tasks have greater opportunities to reallocate their workforce towards a higher share of non-routine jobs, than firms that initially have a low share of routine jobs. Columns 1, 3 and 5 show estimations on the group of firms with high initial average routineness. The corresponding regressions on low routineness firms are presented in columns 2,4 and $6 .{ }^{12}$

Looking across the different estimated coefficients, we note that the pattern presented in Figure 4 above -showing evidence on within-firm job polarization- corresponds to firms with high initial routineness among their workforce. For instance, comparing columns 1 and 2 we can see that the increase in employment for the highwage group comes from firms that initially can be characterized as high-routine. These are firms with high shares of routine jobs at the beginning of the period and in which opportunities for de-routinization have implied a higher relative demand for high-wage jobs. For firms that initially can be characterized as low-routine, we notice a small decline in high-wage jobs at the beginning of the time period that becomes insignificant in the most recent period.

The same pattern is also observed for the demand for low-wage jobs in highroutine firms (compare columns 5 and 6). For these firms, we notice a clear increase in employment for low-wage occupations. These results, in combination with decreasing demand for middle-wage workers in firms with high initial average routineness (column 4), are consistent with routine-biased technological change as an explanation for job polarization. If we instead study firms with low initial average routineness, we do not note any job polarization (columns 1, 3 and 5).

Overall, the results in panel a in Table 3 indicate that the initial composition of the workforce in terms of the degree of routineness and its change over time are systematically related to the observed pattern of within-firm job polarization.

12. See Heyman et al. (2016) for details. 
Panel $b$ shows similar results on the impact of offshorability. The measure of offshorability of jobs is identical to the measure used in e.g. Goos et al. (2014) and originates from BLINDER, KRUEGER (2013). We now take into account firms' occupational structure and the offshorability of these occupations to see how this is associated with the relative demand for the three different wage groups. Differences in offshorability among the firms' workforce are not systematically related to job polarization (see columns in panel b). The only exception is for low-wage workers.

Finally, a similar pattern can be seen when we look at automation risks for occupations. Results are presented in panel c. The measure of automation of jobs is the same as in FREY, OSBORNE (2013). They have estimated the extent to which new technology can replace labor for individual occupations in the US labor market in 2010. Approximately 47 percent of total employment in the US are at risk of being automated within one to two decades. The probabilities of automation have been converted to the Swedish classification of occupations (see Heyman et al., 2016, for details).

Similarly to what is found for the offshorability of jobs, no systematic pattern of job polarization can be observed for automation risks. Given the close relationship between an occupation's routineness and its risk of being automated, we have also analyzed combinations of routineness and automation risks (not shown). For these combinations, the degree of routineness of the initial composition of the workforce is more important than the corresponding classification of firms in terms of automation risks. The same pattern also emerges when we study combinations of firms' workforce in terms of routineness and offshorability. These results again suggest that routinebiased technological change is an important explanation for job polarization.

We conclude that the results in Table 3 indicate that de-routinization is the most important explanation for the observed within-firm job polarization depicted in Figure 4. We also note that the results on high-routine firms and high-wage jobs are in accordance with the previously presented results on skill-upgrading among globalized firms. For instance, acquisitions of local firms by MNEs lead to an increase in highwage jobs, characterized by less routine.

One puzzle that remains for future research to investigate is the increase in demand for low-wage jobs in firms that initially can be characterized as high-routine. This is, however, offset by a corresponding decrease in demand for low-wage jobs in low-routine firms, implying a rather unchanged share of low-wage occupations when studying within-firm dynamics (Figure 4). In combination with a decreasing demand for middle-wage jobs (originating from firms that initially can be characterized as highroutine), the increase in within-firm employment originates from high-wage firms. This is in accordance with results presented above on a skill-upgrading of globalized firms, with increasing demand for high-skilled occupations (Figures 1, 5 and Table 2). These high-skilled, high wage occupations are also characterized by less routine.

The above results and discussion show that there is a relationship between the level of international activities and the demand for high-skilled occupations. An important 
question is whether this relationship is a causal relationship. For instance, a firm's technological development could lead both to an increased demand for a highly skilled workforce and increased competitiveness, thereby increasing its international activities.

To estimate the causal effect of increased export shares on the skill mix at firmlevel, DAVIDSON et al. (2017) use an instrumental variables method and construct instruments for export shares in order to control for time-varying unobserved factors that are correlated with export shares and skill mix. More specifically, they use changes in global supply and demand for goods produced by Swedish firms. ${ }^{13}$ The reasoning behind this approach is that when global demand (import) increases, there is a positive export shock for Swedish firms producing these goods. Likewise, an increased global supply of inputs constitutes a positive import shock for Swedish firms using these imported inputs.

The results in DAVIDSON et al. (2017) show that there is a causal relationship between international trade and the share of high-skilled workers. However, the mechanism behind this effect looks different for exports compared to the import of inputs (offshoring).

When Swedish firms experiencing an exogenous positive increase in demand (a positive export shock) increase their exports, the share of employees working in high-skilled occupations also increases. One may break down this effect for different employee categories. Such a breakdown shows that the increase applies to both whiteand blue-collar workers. In other words, increased exports lead to more white-collar workers working in relatively skilled occupations and fewer in less skilled occupations, and the same applies to blue-collar workers.

The effect of offshoring is a similar increase in the share of white-collar workers and a similar increase in high-skilled white-collar occupations, but it also results in an increase in less skilled blue-collar occupations.

Globalization has increased substantially over the last few decades. As a result, production patterns have changed and with them, the demand for different types of workers. In this paper, we have looked at the effects of some of these changes on the labor market. Firstly, we have shown that the overall distribution of occupations in Sweden has become more skill-intensive over time. There are more people working in relatively skilled occupations today than in the 1990s. The increasingly skilled distribution is not, however, caused by a decline in the lowest skilled occupations. On the contrary, both the lowest and the highest skilled occupations have increased their employment shares. The share of medium skilled occupations has declined, which altogether has led to an increased job polarization.

13. This method is increasingly used in international economics and was first developed by HuMMELs et al. (2014). 
We have then examined the role of globalization in changing the distribution of occupations. We have found that globalized firms have a more skilled distribution of occupations than less globalized firms. More precisely, multinational firms have a more skilled distribution than firms that only sell their products on the local market. Exporting firms have a distribution which is less skilled than multinational firms but more skilled than local firms. Again, the share of low-skilled employees has increased, which suggests that this share might have increased in local firms, an issue that future research might shed new light on.

\section{REFERENCES}

ACEMoglu, D., Autor, D. (2011). "Chapter 12 - Skills, Tasks and Technologies: Implications for Employment and Earnings." In O. Ashenfelter, D. Card (Eds.), Handbook of Labor Economics, vol. 4, part B (pp. 1043-1171). Elsevier. https://doi.org/10.1016/S0169-7218(11)02410-5.

Adermon, A., Gustavsson, M. (2015). "Job Polarization and Task-Biased Technological Change: Evidence from Sweden, 1975-2005.” The Scandinavian Journal of Economics, 117(3), 878-917. https://doi.org/10.1111/sjoe.12109.

Asplund, R., BARTh, E., LundBorg, P., Nilsen, K. M. (2011). "Polarization of the Nordic Labour Markets." Finnish Economic Papers, 24(2), 87-110.

AutoR, D. H. (2013). “The 'Task Approach' to Labor Markets: An Overview.” Journal for Labour Market Research, 46(3), 185-199. https://doi.org/10.1007/s12651-013-0128-z.

AuTOR, D. (2014). Polanyi's Paradox and the Shape of Employment Growth. NBER Working Paper, no 20485.

Autor, D., Dorn, D. (2009). "This Job is 'Getting Old': Measuring Changes in Job Opportunities using Occupational Age Structure." American Economic Review, 99(2), 45-51. https://doi.org/10.1257/aer.99.2.45.

Autor, D. H., Dorn, D. (2013). “The Growth of Low-Skill Service Jobs and the Polarization of the US Labor Market." American Economic Review, 103(5), 1553-97. https://doi.org/10.1257/ aer.103.5.1553.

Autor, D. H., Levy, F., Murnane, R. J. (2003). “The Skill Content of Recent Technological Change: An Empirical Exploration.” The Quarterly Journal of Economics, 118(4), 1279-1333. https://doi.org/10.1162/003355303322552801.

Autor, D. H., KatZ, L. F., Kearney, M. S. (2006). “The Polarization of the U.S. Labor Market.” American Economic Review, 96(2), 189-194. https://doi.org/10.1257/000282806777212620.

Autor, D. H., Dorn, D., Hanson, G. H., Song, J. (2014). "Trade Adjustment: Worker-Level Evidence." The Quarterly Journal of Economics, 129(4), 1799-1860. https://doi.org/10.1093/ qje/qju026.

Autor, D., Dorn, D., Hanson, G., Majlesi, K. (2016). Importing Political Polarization? The Electoral Consequences of Rising Trade Exposure. NBER Working Paper, no 22637. 
Autor, D., Dorn, D., Hanson, G. (2017). When Work Disappears: Manufacturing Decline and the Falling Marriage-Market Value of Young Men. NBER Working Paper, no 23173.

BALdwin, R. E. (2016). The Great Convergence: Information Technology and the New Globalization. Cambridge, Massachusetts: The Belknap Press of Harvard University Press.

Baumgarten, D., Geishecker, I., Görg, H. (2013). "Offshoring, Tasks, and the Skill-Wage Pattern." European Economic Review, vol. 61, 132-152. https://doi.org/10.1016/j. euroecorev.2013.03.007.

Becker, S. O., Ekholm, K., Muendler, M.-A. (2013). "Offshoring and the Onshore Composition of Tasks and Skills." Journal of International Economics, 90(1), 91-106. https:// doi.org/10.1016/j.jinteco.2012.10.005.

Bernard, A. B., Jensen, J. B. (1997), “Exporters, Skill Upgrading, and the Wage Gap.” Journal of International Economics, 42(1-2), 3-31. https://doi.org/10.1016/S0022-1996(96)01431-6.

Blinder, A. S. (2006). “Offshoring: The Next Industrial Revolution?” Foreign Affairs, 85(2), 113-128. https://doi.org/10.2307/20031915.

Blinder, A. S., Krueger, A. B. (2013). "Alternative Measures of Offshorability: A Survey Approach.” Journal of Labor Economics, 31(S1, part 2), S97-S128. https://doi. org/10.1086/669061.

Colantone, I., Stanig, P. (2018a). "Global Competition and Brexit." American Political Science Review, 112(2), 201-218. https://doi.org/10.1017/S0003055417000685.

Colantone, I., Stanig, P. (2018b). "The Trade Origins of Economic Nationalism: Import Competition and Voting Behavior in Western Europe." American Journal of Political Science, 62(4), 936-953. https://doi.org/10.1111/ajps.12358.

Davidson, C., Heyman, F., Matusz, S., Sjöholm, F., Zhu, S. C. (2017). “Global Engagement and the Occupational Structure of Firms." European Economic Review, vol. 100, 273-292. https://doi.org/10.1016/j.euroecorev.2017.08.009.

Dippel, C., Gold, R., Heblich, S. (2015). Globalization and its (Dis-)Content: Trade Shocks and Voting Behavior. NBER Working Paper, no 21812.

Dunning, J. H. (1981). International Production and the Multinational Enterprise. London: Allen \& Unwin.

FeEnstra, R. C., MA, H., Xu, Y. (2017). US Exports and Employment. NBER Working Paper, no 24056.

Feenstra, R. C., Sasahara, A. (2017). The "China Shock”, Exports and U.S. Employment: A Global Input-Output Analysis. NBER Working Paper, no 24022.

Frankel, J. A., Romer, D. H. (1999). "Does Trade Cause Growth?” American Economic Review, 89(3), 379-399. https://doi.org/10.1257/aer.89.3.379.

Frey, C. B., Osborne, M. (2013). The Future of Employment: How Susceptible Are Jobs to Computerisation? Working Paper, Oxford: Oxford Martin School. 
Goos, M., Manning, A. (2007). "Lousy and Lovely Jobs: The Rising Polarization of Work in Britain." The Review of Economics and Statistics, 89(1), 118-133. https://doi.org/10.1162/ rest.89.1.118.

Goos, M., Manning, A., Salomons, A. (2009). "Job Polarization in Europe." American Economic Review, 99(2), 58-63. http://doi.org/10.1257/aer.99.2.58.

Goos, M., Manning, A., Salomons, A. (2014). "Explaining Job Polarization: Routine-Biased Technological Change and Offshoring." American Economic Review, 104(8), 2509-2526. https://doi.org/10.1257/aer.104.8.2509.

Grossman, G. M., Rossi-Hansberg, E. (2008). "Trading Tasks: A Simple Theory of Offshoring.” American Economic Review, 98(5), 1978-1997. https://doi.org/10.1257/aer.98.5.1978.

Grossman, G. M., Rossi-Hansberg, E. (2012). “Task Trade between Similar Countries.” Econometrica, 80(2), 593-629. https://doi.org/10.3982/ECTA8700.

Hakkala, K. N., Heyman, F., Sjöholm, F. (2014). "Multinational Firms, Acquisitions and Job Tasks." European Economic Review, vol. 66, 248-265. https://doi.org/10.1016/j. euroecorev.2013.12.003.

Harrigan, J., Reshef, A., Toubal, F. (2016). The March of the Techies: Technology, Trade, and Job Polarization in France, 1994-2007. NBER Working Paper, no 22110.

Helpman, E., Melitz, M.J.,Yeaple, S.R. (2004). “Exports Versus FDI with Heterogeneous Firms.” American Economic Review, 94(1), 300-316. https://doi.org/10.1257/000282804322970814.

Heyman, F. (2016). "Job Polarization, Job Tasks and the Role of Firms." Economics Letters, 145, 246-251. https://doi.org/10.1016/j.econlet.2016.06.032.

Heyman, F., NoRBÄCK, P.-J., PERSSON, L. (2016). Digitaliseringens dynamik-en ESO-rapport om strukturomvandlingen $i$ svenskt näringsliv. Rapport till Expertgruppen för studier i offentlig ekonomi. Stockholm: Wolters Kluwer.

Heyman, F., SנÖHOLm, F. (2018). Globalisering och svensk arbetsmarknad. Stockholm: SNS Förlag.

Hummels, D., Jørgensen, R., Munch, J., Xiang, C. (2014). “The Wage Effects of Offshoring: Evidence from Danish Matched Worker-Firm Data." American Economic Review, 104(6), 1597-1629. https://doi.org/10.1257/aer.104.6.1597.

LEAMER, E. E., STORPer, M. (2001). “The Economic Geography of the Internet Age.” Journal of International Business Studies, 32(4), 641-665. https://doi.org/10.1057/palgrave.jibs.84909988.

Levy, F., Murnane, R. J. (2004). The New Division of Labor: How Computers Are Creating the Next Job Market. New York: Russel Sage Foundation; Princeton, N.J.: Princeton University Press.

MeLITZ, M. J.(2003). “The Impact of Trade on Intra-Industry Reallocations and Aggregate Industry Productivity.” Econometrica, 71(6), 1695-1725. https://doi.org/10.1111/1468-0262.00467.

Michaels, G., NAtraj, A., VAn ReEnen, J. (2014). "Has ICT Polarized Skill Demand? Evidence from Eleven Countries over Twenty-Five Years.” The Review of Economics and Statistics, 96(1), 60-77. https://doi.org/10.1162/REST_a_00366. 
Milanović, B. (2016). Global Inequality: A New Approach for the Age of Globalization. Cambridge, Massachusetts: The Belknap Press of Harvard University Press.

Navaretti, G. B., Venables, A. J. (2004). Multinational Firms in the World Economy. Princeton, NJ: Princeton University Press.

PekKala Kerr, S., Maczulskij, T., Maliranta, M. (2016). Within and Between Firm Trends in Job Polarization: Role of Globalization and Technology. Working Papers, no 308, Helsinki: Labour Institute for Economic Research.

Pierce, J. R., Schott, P. K. (2016). Trade Liberalization and Mortality: Evidence from U.S. Counties. NBER Working Paper, no 22849.

Rodrik, D. (2018). "Populism and the Economics of Globalization.” Journal of International Business Policy, 1(1-2), 12-33. https://doi.org/10.1057/s42214-018-0001-4.

Saval, N. (2017). "Globalisation: The Rise and Fall of an Idea that Swept the World". The Guardian. Online https://www.theguardian.com/world/2017/jul/14/globalisation-the-rise-andfall-of-an-idea-that-swept-the-world (accessed 18 June 2019).

SpItz-Oener, A. (2006). “Technical Change, Job Tasks, and Rising Educational Demands: Looking outside the Wage Structure.” Journal of Labor Economics, 24(2), 235-270. https:// doi.org/10.1086/499972. 
